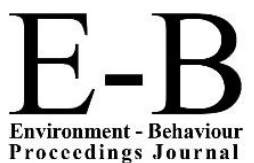

Environment - Behaviour
Procecdings Journal

\section{CSSR 2018}

https://cssr.uitm.edu.my/2018/

5 th International Conference on Science and Social Research

Le Meridien Kota Kinabalu Hotel, 5 - 6 December 2018

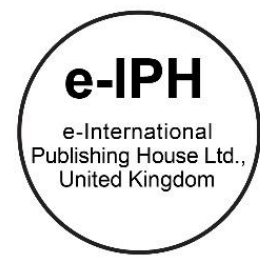

\title{
The Importance of Quality Product Design Aspect based on Computer Aided Design (CAD)
}

\section{Baharudin Saleh ${ }^{1}$, Mohamad Sattar Rasul'1, Haryanti Mohd Affandi2, Indera Irawan Md Rawi Chandran ${ }^{3}$.}

\author{
${ }^{1}$ Faculty of Education, Universiti Kebangsaan Malaysia, 43600 Bangi, Selangor, Malaysia \\ ${ }^{2}$ Faculty of Engineering and Built Environment, Universiti Kebangsaan Malaysia, 43600 Bangi, Selangor, Malaysia \\ ${ }^{3}$ Faculty of Design and Built Environment, First City University College, 47800 Petaling Jaya, Selangor, Malaysia
}

p83713@siswa.ukm.edu.my, drsattar@ukm.edu.my, haryantima@ukm.edu.my, indera.chandran@firstcity.edu.my

Tel: +60192406058

\begin{abstract}
Computer-Aided Design (CAD) is the essential tools to create technical documentation and product specification for designing a product. Because of this, a survey conducted to identify the needs and importance of the design aspect such as design requirement, design concept, detailed product design and design evaluation. The result of a descriptive analysis indicated that significance of the elements of designing the quality product was at a high level. Findings also state that there was a positive relationship between the design process among each aspect of the product design, and the correlation shows a moderate level.
\end{abstract}

Keywords: Design Requirement; Design Concept; Detailed Product Design; Design Evaluation.

eISSN: 2398-4287C 2020. The Authors. Published for AMER ABRA cE-Bsby e-International Publishing House, Ltd., UK. This is an open access article under the CC BYNC-ND license (http://creativecommons.org/licenses/by-nc-nd/4.0/). Peer-review under responsibility of AMER (Association of Malaysian Environment-Behaviour Researchers), ABRA (Association of Behavioural Researchers on Asians) and cE-Bs (Centre for Environment-Behaviour Studies), Faculty of Architecture, Planning \& Surveying, Universiti Teknologi MARA, Malaysia.

DOI: https://doi.org/10.21834/ebpj.v5iSI3.2545

\subsection{Introduction}

The technology on the product design process was developing and gave high impact positively. The product designs were expanding well throughout the entire world and become the critical production of human needs. Therefore product design needs a systematic and complete working plan to produce quality products (Sulaiman et al. 2011). The product must design based on the standard criteria (Tayal, 2013). There would be minimal on the production cost if the products were developed in full fill the quality and the specification needed (Bon, 2010). Therefore, the manufacturing industry should adapt into increase productivity by taking action on minimum the product cost, responding to rapid changes and manufacturing, and optimize the design process to complete specific tasks (Schey, 2009).

Product design development becomes more important to attract consumers interim on functional and the use of the products (Harston, 2012). The consumer or the user will become loyal if they purchase and use the right product designed (Shaukat, 2012). The attractive and high-quality designs depend on product characteristics such as aesthetics, ergonomics (Kroemer, Kroemer \& Kroemer-Elbert, 2001), colours, overall shape, functionality (Ma, Chen, \& Wu, 2007), safety, and others much affect the user's choice of products (Soni, Khanna, \& Tandon, 2013).

The purpose of this study is to identify the requirement and the importance of the development of developing the model and its relationship with the CAD- and quality product design. This design model is essential to prepare as most students lacked soft skills such as critical thinking, communication, and innovation (EPU, 2015). During the product development stage, it requires a sustainable

eISSN: 2398-4287C 2020. The Authors. Published for AMER ABRA cE-Bsby e-International Publishing House, Ltd., UK. This is an open access article under the CC BYNC-ND license (http://creativecommons.org/licenses/by-nc-nd/4.0/). Peer-review under responsibility of AMER (Association of Malaysian Environment-Behaviour Researchers), ABRA (Association of Behavioural Researchers on Asians) and cE-Bs (Centre for Environment-Behaviour Studies), Faculty of Architecture, Planning \& Surveying, Universiti Teknologi MARA, Malaysia.

DOI: https://doi.org/10.21834/ebpj.v5iSI3.2545 
ecosystem of innovation which is a somewhat tricky element to implement. Supported data from the analysis report on student design work in the field of Design and Technology in the subject of Computer-Aided Design (CAD) shows that $65 \%$ of students weak on the aesthetics element such as product features, product finishes, and product functions. Another $55 \%$ of students not mastering on the ergonomic element encompassing the characteristics of product comfort to consumers and the functionality of the product. While $60 \%$ of students are unclear in the initial idea development such as finding information on products to be designed and translated in the form of idea sketches on product characteristics (Unit Penilaian dan Pentaksiran IPGKPT, 2016).

The weakness of students in aesthetics, ergonomics and the idea development on the product design will show that there was less quality and less authentic. The results of the study conducted by Hassan, Ismail \& Mustapha (2012), on Polytechnic students in Malaysia showed that the creativity of the students was similar to the findings from the analysis report on IPG. The result showed there was a significant difference in the idea of a product design prefix in synthesis activities using the CAD technology integration (M $=80.6)$ compared to the synthesis activities using conventional methods $(M=67.1), t(1.18)=17.18$. The findings prove that creative design can generate from the integration of technology is better than conventional methods. Synthesis activities with problem-solving elements are also essential to highlight more creative ideas in the process of designing a product that meets the needs of consumers (Mao et al., 2011).

\subsection{Methodology}

The survey research conducted to identify the development needs of the CAD product design model regarding product design requirements, product design conceptual aspects, product detail design aspects and product design assessment aspects. The researcher built the questionnaire instrument for this requirement analysis from the previous research and literature study questions. The Cronbach's Alpha value for the entire questionnaire for the pilot study was 0.945 . This study uses descriptive analysis to obtain standard deviation value and min. Therefore, the sample size determination in this phase is based on the sample size determination table by Krejcie, \& Morgan (1970), which taking into account the identified population is close to 340 . The sample size for this phase study is 181 respondents consisting of the students from the program of Bachelor's Degree in Design and Technology Courses at Teacher Institute (IPG) throughout Malaysia. In this study, researchers use multiple stratified random or random sampling methods. This method chose because it will able to increase the probability of students in the population to be selected as a sample of the study (Gray, 2013) and improved the accuracy of the results of the survey (Hancock \& Mueller, 2010).

Results from questionnaire instruments were analyzed using the SPSS version 20 software. Descriptive analysis in the form of the mean index, standard deviation, frequency, and a percentage used to determine the requirements of the CAD-based quality product design model developed. The descriptive analysis also will be carried out to identify the importance of CAD-based product design process. Pearson's correlation analysis will apply on the inference analysis which will apply on the null hypothesis $(\mathrm{Ho})$, where to see the relationship between the design requirements and the concept design and the relationship between the design detailing the study. To assess the strength of correlation (r), Cohen (1998) recommends the following values: $r=0.001-0.29$ (low), $r=0.30-0.49$ (moderate), $r=0.50-1.00$ (height).

\subsection{Findings and Discussion}

The design model needs in the production of a quality product highly demanded. The findings in Table 1 show that the majority of students $(98.3 \%$ ) have never exposed to problem-solving design concepts in generating creative ideas in product design processes. The proved to problem-solving design concepts that need to be taken seriously because the creating of a preliminary idea is a basic necessity for a student in producing quality, creative and innovative design products (Chulvi et al., 2013; Tayal, 2013). The findings of this study are similar to Yunus, Harris, \& Hafiz (2006), which they report that the majority of product designs do not have real design concepts that meet the aesthetic, ergonomic and creative features of the product. The weaknesses also identified in the Design and Technology (RBT) student analysis coursework reported in the CAD subject showed that $60 \%$ of the students were unclear in the initial idea initiation such as finding information on the product design process and idea development through sketches including an aesthetic and ergonomic element in designing the innovative products (Unit Penilaian \& Pentaksiran IPGKPT, 2016). Therefore, the importance of idea development and basic the ideas for product design concepts can trigger by the application on the critical thinking with the systematic process (Choo et al., 2011; Sulaiman et al., 2011).

Table 1. Student Exposure on Product Design Model Needs

\begin{tabular}{|l|c|c|}
\hline \multicolumn{1}{|c|}{ Aspect } & Yes & No \\
\hline The concept of TRIZ copyrighted problem-solving design (Teoriya, Resheniya, lzabretatelskikh, Zadach)? & $3(1.7 \%)$ & $178(98.3 \%)$ \\
\hline The CAD-based quality product design model that directly leads to teaching and learning? & $7(3.9 \%)$ & $174(96.1 \%)$ \\
\hline
\end{tabular}

The findings show that the majority of the students (96.1\%) have never been exposed to a CAD-based product design model in the learning process to produce product designs (Table 2). The findings of this study show the need for the development of a specific product design model developed. Therefore, this result is in line with Osakue (2015) who pointed out that students can produce product designs that meet the physical features of the product such as size, colour, surface finish and significant product dimensions. It is corroborated with the study by Kusar et al. (2004), identified that other requirement, such as the specific steps in making particular decisions associated with the development of CAD-based product design. Hence to get quality products, Summers \& Shah (2010) 130 
explains that design errors can happen because of not following the design sequences process, which involves CAD. Therefore, every sequence in the design process, which include the design elements become the guideline to produce quality product designs.

Table 2 shows the findings on the importance of the design elements in the product design requirements. The average score of the significance of the design requirement aspect is $4.48(S D=0.403)$. This result shows that the importance of the design element is at a very high level and is indispensable in the process of designing a quality product. This result corresponds to Ulrich \& Eppinger (2012), stated the first aspect of identifying for design requirement is the analysis of design problems faced by the user through an in-depth study which needs to be done by the designer. Detailed, the mean value of each design element such as finding information (mean = 4.42), making comparisons (mean $=4.46$ ) and reviewing the information (mean $=4.46$ ) design from the perspective of the user is high and most necessary in the process of designing the product. This finding coincides with the study by Tayal (2013) which mentioned the critical the undertaking exploration, make the comparison and analyze the various designs to create a quality product design. According to Taib \& Hanafiah (2006) and Jalil (2000), mentioned that after identifying the design problems including the aesthetics, ergonomics, colours, and safety, the detailed methods of settlement should implement during the design process. This design problems is in line with the findings of the mean value of the study elements in identifying the design problems (mean $=4.58$ ) and applying the problem-solving method in the process of product design information study (mean $=4.50$ ). The findings of this study are in line with the survey by llevbare Probert \& Phaal (2013) \& Jin \& Li (2009) that the product design process also involves with the discussions on various product designs with the brainstorming activities, adding creative ideas with problem-solving methods.

Table 2. Importance of Design Elements in Product Design Requirements

\begin{tabular}{|c|l|c|c|}
\hline No & \multicolumn{1}{|c|}{ Element } & Mean & SD \\
\hline 1 & Analyze product design information from the multiple sources & 4.42 & 0.667 \\
\hline 2 & Make comparisons of various product designs or existing products & 4.46 & 0.582 \\
\hline 3 & Review the information provided by the customer & 4.46 & 0.654 \\
\hline 4 & Identify design problems faced by users such as aesthetics, ergonomics, colour and product safety features & 4.58 & 0.587 \\
\hline 5 & Apply the problem-solving methods in the process of product design information study. & 4.50 & 0.574 \\
\hline & \multicolumn{1}{|c|}{ Total } & 4.48 & 0.403 \\
\hline
\end{tabular}

Notes: Mean 1.00-1.80=Very low, 1.81-2.60=Low, 2.61-3.40=Moderate, 3.41-4.20=High, 4.21-5.00=Very high

Table 3 shows the findings of the importance level of design elements in the aspect of the product design concept. Coincide with the findings, as shown in Table 5; all mean values for each element are very high (above mean value 4.21). Suggestion ideas (mean = 4.49 ), idea generation process (mean $=4.63$ ) and list ideas (mean $=4.51$ ) product design. This finding supports Choo et.al. $(2011)$ statement that design concepts can trigger by the addition of ideas and critical thinking to systematic processes (Sulaiman et al., 2011). The findings also show that the importance of design elements in the perspective of students, such as making free-hand sketches (mean $=4.49$ ). Similar to the study by Hussain $(2004)$, the findings of this study illustrate the importance of the sketches elements of the idea development is a part of the design process stage. It also can be evaluated and develop it into the final concept, which will meet the specification of the product design process (Jalil, 2000; Ulrich \& Eppinger, 2012). Thus, designers can produce as many ideas as possible by using various methods such as brainstorming, checklists, and morphological charts during the design process. Accordingly to Baddam, 2014 and Ulrich \& Eppinger, 2012, after identifying the final concept, the detailing design process will start to ensure that the primary features such as sizes, colors, packagings, and dimensions will be applied in the design process. The $3 \mathrm{D}$ design drawing by using the CAD software will translate the details of design components such as drawing scale (Hassan et. al, 2016; Osakue, 2015). It will help to produce the dimension and a list of the material and standard engineering drawing format on the product designed (Company et al., 2015; Quintana et al., 2010; Jalil 2000).

Table 3. The Importance of Design Elements in Product Design Concept

\begin{tabular}{|c|l|c|c|}
\hline No & \multicolumn{1}{|c|}{ Main Element } & Mean & SD \\
\hline 1 & Provide the product design idea which covers the interests of various parties (consumers, industries, and others). & 4.49 & 0.523 \\
\hline 2 & Generate creative ideas and basic product principles in the product design process & 4.63 & 0.517 \\
\hline 3 & List the ideas for brainstorming sessions in the process of the product designs. & 4.51 & 0.534 \\
\hline 4 & Create free-hand sketches to help designers handle different design concepts. & 4.49 & 0.534 \\
\hline 5 & Make improvements based on the selection of end design concepts that meet the design specifications. & 4.46 & 0.582 \\
\hline & Total & 4.50 & 0.331 \\
\hline
\end{tabular}

Notes: Mean 1.00-1.80=Very low, 1.81-2.60=Low, 2.61-3.40=Moderate, 3.41-4.20=High, 4.21-5.00=Very high

The findings in Table 4 show all elements on a very high mean value exceeding 4.21 which show that the final design sketches to $3 \mathrm{D}$ modelling, final design result, aesthetic, ergonomic, scale measurement and real images is critical. This finding also explains that all the design elements in the design detailing become essential during the design process with an average mean score of 4.58. Equivalent to the statement by Allen \& Pearson (2016) and Tang et al. (2014), mentioned with CAD software, it will help students or designers to produce quality, especially in $3 \mathrm{D}$ drawing.

Table 4. Level of Importance of Design Elements in Product Design Detailing

\begin{tabular}{|l|l|l|l|}
\hline No & Main Element & Mean & SD \\
\hline
\end{tabular}




\begin{tabular}{|c|c|c|c|}
\hline 1 & Transfer final design sketches into 3D CAD & 4.57 & 0.528 \\
\hline 2 & Produce end design based on aesthetic and ergonomics by using CAD & 4.62 & 0.531 \\
\hline 3 & $\begin{array}{l}\text { Consider the physical features of the product such as size, colour, surface finish and significant product dimensions } \\
\text { for the product design process }\end{array}$ & 4.60 & 0.513 \\
\hline 4 & Scaling the product by using the CAD. & 4.52 & 0.533 \\
\hline \multirow[t]{2}{*}{5} & Application material images by using the CAD & 4.58 & 0.517 \\
\hline & Total & 4.58 & 0.379 \\
\hline
\end{tabular}

Notes: Mean 1.00-1.80=Very low, 1.81-2.60=Low, 2.61-3.40=Moderate, 3.41-4.20=High, 4.21-5.00=Very high

Table 5 is an analysis of the design elements in design evaluation aspects for the creation of CAD-based on quality products. The elements contained were evaluated the design regarding the planning ability, the product quality, the product justification for the final stage and the design competence rubric. Based on table 5, there were four items identified for design elements in product design evaluation. The analysis of each item indicates that the majority of the students agree on the importance of design evaluation on all design elements with the mean score between 4.55 (very important) to 4.60 (very important).

Table 5. The Importance of Design Elements in the Product Design Evaluation

\begin{tabular}{|c|l|c|c|}
\hline No & \multicolumn{1}{|c|}{ Main Element } & Mean & SD \\
\hline 1 & Evaluate working plan, planning ability, info research and creativity idea. & 4.55 & 0.581 \\
\hline 2 & Evaluate product quality based on originality, finishing, ergonomic, aesthetic and product safety & 4.58 & 0.558 \\
\hline 3 & Evaluate the outcome of the product design by observing and justify the quality of the design. & 4.56 & 0.550 \\
\hline 4 & Evaluate the quality of the product designed through the competence rubric development. & 4.60 & 0.525 \\
\hline & & 4.57 & 0.406 \\
\hline
\end{tabular}

Notes: Mean 1.00-1.80=Very low, 1.81-2.60=Low, 2.61-3.40=Moderate, 3.41-4.20=High, 4.21-5.00=Very high

This finding illustrates that the production of quality designs and the design assessments are also an essential aspect in determining the competence of students. Although the teacher has a lot of time to make observations during the design process in the classroom, the products designed that to be evaluated in manually are insufficient (Nurhibatullah, 2014). The methods such as analytical evaluation (Jamaluddin et. al., 2012) and holistic assessment can give a clear overview of the product design process (Ministry of Education, 2016). Although the student's perspective shows the design aspect of the product design is very important, still student designs outcome doesn't show the concrete of the design concepts that meet the aesthetic, ergonomic and creative characteristics (Yunus, Harris \& Hafiz, 2006). Therefore, the evaluation by using rubric competence which listed the detailed drawing elements of CAD can evaluate in term of aesthetics, ergonomics, colour, usability, and safety needs to develop (Taib \& Hanafiah., 2006; Ulrich \& Eppinger 2012; Chen \& Wang, 2012; Makhbul, 2012; Pheasant, \& Haslegrave, 2016). According to the students perspective, they're assumed that the design aspect of the detailing design is the most important compared to other elements (design requirements, concept design, and design evaluation).

Table 6 shows the correlation values among design processes, design requirements, concept designs, detailed designs and product evaluations. The positive correlation value is straightforward given for the design process with design requirements $(r=0.354)$. The design concepts and designs detailing are positively correlated with the design process $(r=0.430$ and $r=0.425)$. The design evaluation aspect is moderately correlated with the design process $(r=0.476)$. Significant value for all aspects studied is $p=0.000$ $<0.01$. Therefore, reject the $\mathrm{H}_{0}$ where it states that there is no significant relationship between the design process with design requirements, concept design, detailed design and design evaluation in designing. This decision finds that all aspects have a good relationship with the design process when designing the product is implemented, but the relationship is at a moderate level. Corresponding to the design model proposed by Ulrich \& Eppinger (2012), emphasis on the customer requirement information analysis, conceptualization, initial and advanced improvements and the final design concept becomes the important and interdependent phase. There were similarities with the design model by Ulrich, \& Eppinger (2012) and Pugh \& Clausing (1996), emphasizes the design model must include the product design specs, conceptual designs, design details.

Table 6. The Relationship Between Design Processes with Designer Requirements, Design Concept, Design Detailing and Design Evaluation in Their Forms of Product

\begin{tabular}{|c|c|c|c|c|c|}
\hline \multicolumn{2}{|c|}{} & Design Requirement & Design Concept & Design Detailing & Design Evaluation \\
\hline \multirow{3}{*}{ Design Process } & Pearson Correlation & $.354^{* *}$ & $.430^{* *}$ & $.425^{* *}$ & $.476^{* *}$ \\
\cline { 2 - 6 } & Sig. (2-tailed) & .000 & .000 & .000 & .000 \\
\cline { 2 - 6 } & $\mathrm{N}$ & 181 & 181 & 181 \\
\hline \multicolumn{4}{|c|}{${ }^{* *}$. Correlation is significant at the 0.01 level (2-tailed). } \\
\cline { 2 - 6 }
\end{tabular}

Although there was a good relationship between the aspects studied with the design process, its interrelation at a modest level. This finding demonstrates that students need to empower the design aspects required in the product design process with the elements of creativity and innovation. Corresponding to the views expressed by Le Masson, Weil and Hatchuel (2010), the innovation elements also play an essential role in promoting creative and creative ideas in the production of quality product designs. Hence, the purpose of this initial study is to identify the need and importance of developing a CAD-based design model in producing quality products. Mastering the design aspect can be implemented if some weaknesses in innovation ecosystems such as weak on the ergonomic 
element, unclear in the initial idea development and translated the idea in the form of an idea sketch on product characteristics (Unit Penilaian dan Pentaksiran IPGKPT, 2016).

There also lack critical thinking skills among students from the lower level to IPT level. Most students require soft skills such as critical thinking, communication, and innovation (EPU 2015). Soft skills are needed because it becomes a synthesis activity with problem-solving elements. Creative ideas in the design process will meet the needs of consumers. Mao et al., 2011 and Sulaiman et al., 2011 also highlight the design process is the most critical process which must meet the specifications and the consumer demand. Hence, problem-solving and creative thinking are required to provide ideas for product design development (Chulvi et al., 2013). Therefore, there is a need to develop a specific model for CAD-based product design in producing quality products and meeting specified specifications. CAD is a tool that applies and covers every design process requirement.

\subsection{Conclusion \& Recommendations}

Product design development is a process that involves many considerations and decisions in different levels method. Design concepts become crucial in realizing the development of quality products at the starting process with the idea of creating quality product design. At the stage of brainstorming, a systematic method needs to apply that can generate innovation and creative problem-solving. One of the purposes is research on consumer request and needs. While on product design detailing stage can highlight the design concept by using the $C A D$ application. The $C A D$ can help in creating product designs ranging from the stage of a product design concept to the technical documentation. The use of CAD will save time and energy for the design process and the manufacturing process. Furthermore, this study can help provide empirical evidence of the importance and requirements of the design element to produce a quality product design and meet the standards specification.

\section{Acknowledgements}

An Appreciation to the Ministry of Education Malaysia (MOE) and Universiti Kebangsaan Malaysia for co-operating in carrying out this study.

\section{References}

Allen, L. \& Pearson, L. C. (2016). The Past, Present and Futures of Drawing. Drawing Futures, Speculations in Contemporary Drawing for Art and Architecture. 3-4.

Baddam, M. R. (2014). Right Approach To 3D Modeling Using CAD Tools. Texas A\&M University-Kingsville.

Bon, A. T. (2010). Pengurusan kejuruteraan. Penerbit UTHM.

Chen, K.-M. \& Wang, M.-J. (2012). Computer aided three-dimensional colour planning and visualization system for product design. Journal of the International Colour Association, 7, 1-26.

Company, P., Contero, M., Otey, J. \& Plumed, R. (2015). Approach for developing coordinated rubrics to convey quality criteria in MCAD training. CAD Computer Aided Design,63, 101-117.

Choo, A. M., Weng, N. K., \& Ghazali, F. H. M. (2011). Pencetusan Idea Reka Bentuk Produk Mengguna TRIZ. Jurnal Teknologi Maklumat \& Multimedia, 11, 1-9.

Chulvi, V., González-Cruz, M. C., Mulet, E. \& Aguilar-Zambrano, J. (2013). Influence of the type of idea-generation method on the creativity of solutions. Research in Engineering Design, 24(1), 33-41.

EPU. (2015). Kertas 21: Inovasi Penjana Kekayaan. Putrajaya: Jabatan Perdana Menteri.

Gray, D. E. 2013. Doing research in the real world. Sage.

Hancock, G. R. \& Mueller, R. O. 2010. The reviewer's guide to quantitative methods in the social sciences. Routledge.

Harston, S. P. (2012). A Methodology for Strategically Designing Physical Products that are Naturally Resistant to Reverse Engineering. Brigham Young UniversityProvo. Retrieved October 10, 2017, from https://search.proquest.com/docview/1015155442?accountid=27931

Hassan, I. S., Mohd. Arif Ismail, \& Mustapha, R. (2016). Model Digital Dengan Autocad: Dari Abstrak Ke Realiti. Penerbit Universiti Kebangsaan Malaysia.

Hassan, I. S., Ismail, M. A., \& Mustapha, R. (2012). Mobile and CAD Technology Integration Effects on Designing Process of Malaysian Polytechnic Architecture Student in Producing a Creative Product. Journal Online Jaringan Pengajian Seni Bina (JOJAPS), pp. 1-11.

Hussain, M. N. (2004). Rekabentuk Industri Dalam Menjana Kretiviti Jurutera. Conference On Engineering Education (CEE 2004), pp. 1-5

Ilevbare, I. M., Probert, D. \& Phaal, R. (2013). A review of TRIZ, and its benefits and challenges in practice. Technovation, 33(2-3), 30-37.

Jalil, M. K. A. (2000). Proses dan Kaedah Reka Bentuk. Penerbit UTM. 
Jamaluddin, Z., Razali, A. M., \& Mustafa, Z. (2012). Persepsi ke atas penggunaan alat dan teknik kualiti terhadap prestasi kualiti dalam industri pembuatan. Journal of Quality Measurement and Analysis (JQMA), 8(2), 1-8.

Jin, Y. T. \& Li, S. C. (2009). TRIZ: Systematic innovation in manufacturing. Firstfruits Publishing.

Krejcie, R. V \& Morgan, D. W. 1970. Determining sample size for research activities. Educational and psychological measurement, 30(3), 607-610.

Kroemer, K. H. E., Kroemer, H. B. \& Kroemer-Elbert, K. E. (2001). Ergonomics : how to design for ease and efficiency. Upper Saddle River, NJ: Prentice Hall.

Kusar, J., Duhovnik, J., Grum, J. \& Starbek, M. (2004). How to reduce new product development time. Robotics and Computer-Integrated Manufacturing, $20(1), 1-15$.

Lee, S. \& Koubek, R. J. (2010). Understanding user preferences based on usability and aesthetics before and after actual use. Interacting with Computers, 22(6), 530543.

Ma, M. Y., Chen, C. Y. \& Wu, F. G. (2007). A design decision-making support model for customized product color combination. Computers in Industry, 58(6), 504-518.

Makhbul, Z. M., \& Hasun, F. M. (2007). Ergonomik dan stres di Malaysia: Implikasi terhadap teori, metodologi dan pengurusan. Jurnal Pengurusan (UKM Journal of Management), 26.

Mao, A., Luo, J., Li, Y., Luo, X. \& Wang, R. (2011). A multi-disciplinary strategy for computer-aided clothing thermal engineering design. CAD Computer Aided Design, 43(12), 1854-1869.

Nurhibatullah. (2014). Penilaian Produk "Product Assessment." Retrieved June 29, 2017, from http://nurhibatullah.blogspot.my/2014/01/penilaian-produk-productassessment.html.

Osakue, E. E. (2015). Teaching Solid Modeling with AutoCAD. Age, 26, 1-17.

Pheasant, S. \& Haslegrave, C. M. (2016). Bodyspace: Anthropometry, ergonomics and the design of work. CRC Press.

Pugh, S. \& Clausing, D. 1996. Creating innovtive products using total design: the living legacy of Stuart Pugh. Addison-Wesley Longman Publishing Co., Inc.

Quintana, V., Rivest, L., Pellerin, R., Venne, F. \& Kheddouci, F. (2010). Will Model-based Definition replace engineering drawings throughout the product lifecycle? A global perspective from aerospace industry. Computers in Industry, 61(5), 497-508.

Schey, J. A. (2009). Pengenalan kepada proses pembuatan. Kuala Lumpur: Institut Terjemahan Negara Malaysia.

Shaukat, M. (2012). Influence of product complexity and customer demographics on co-design. The University of Michigan.

Soni, S., Khanna, P. \& Tandon, P. (2013). Knowledge Support System for Aesthetics in Product Design. Journal of Computing and Information Science in Engineering, 13(1), 11006.

Sulaiman, R., Shapi, A., Hasan, M. K., \& Prabuwono, A. S. (2011). Reka bentuk implan sendi pinggul dan penggunaannya dalam persekitaran digital. Sains Malaysiana, 40(11), 1307-1312.

Summers, J. D. \& Shah, J. J. (2010). Mechanical engineering design complexity metrics: size, coupling, and solvability. Journal of Mechanical Design, 132(2), 21004 (111).

Taib, J. M., \& Hanafiah, K. A. (2006). Reka Bentuk Berbantu Komputer-Asas Pemodelan. Penerbit UTM.

Tang, H., Zhou, J., Wang, L., Liao, D. \& Tao, Q. (2014). Development of 2D casting process CAD system based on PDF/image files. China Foundry, 11(5), 440-446.

Tayal, S. P. (2013). Engineering Design Process. International Journal of Computer Science and Communication Engineering, 1-5.

Ulrich, K. T. \& Eppinger, S. D. (2012). Product design and development. New York: McGraw-Hill//rwin.

Unit Penilaian dan Pentaksiran IPGKPT. (2016). Laporan analisis kerja kursus semester lapan pelajar reka bentuk dan teknologi IPGKPT oktober 2016. Bandar Enstek, Negeri Sembilan: Institut Pendidikan Guru Kampus Pendidikan Teknik. 